\title{
Comparison of protocols for the extraction of genomic DNA from Sharpshooters (Hemiptera: Cicadellidae) for the detection of Xylella fastidiosa
}

\author{
Comparação de protocolos para a extração de DNA genômico de \\ cigarrinhas (Hemiptera: Cicadellidae) para a detecção de Xylella fastidiosa
}

\author{
Rúbia de Oliveira Molina ${ }^{*}$, Karina Silva dos Santos², William Mário de Carvalho Nunes ${ }^{3}$

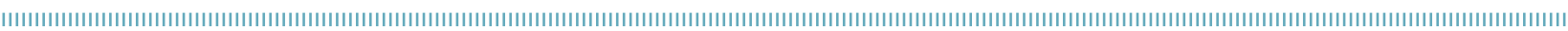

\begin{abstract}
The bacterium Xylella fastidiosa, the causal agent of citrus variegated chlorosis (CVC), is dependent on vector insects for its spread and infection of citrus hosts. The insects, leafhoppers (Hemiptera: Cicadellidae) transmit the bacteria to healthy plants after feeding on infected plants. The objective of this study was to develop and compare methods for extracting genomic DNA from sharpshooters to detect $X$. fastidiosa. The DNA extraction from insects was performed according to a phenol-chloroform based DNA extraction in conjunction with two commercial kits, Dneasy ${ }^{\circledR}$ Plant Mini Kit and blood \& tissue Dneasy ${ }^{\circledR}$ Handbook (Qiagen Inc., Valencia, CA, USA). The heads of the following species of sharpshooter were used: Dilobopterus costalimai, Acrogonia citrina, Oncometopia facialis, Bucephalogonia xanthophis, Macugonalia leucomelas and Homalodisca ignorata. Based on the numeric differences between independent samples, the results showed the use of the phenol:chloroform extraction method ( $36 / 50$ positives) and the DNeasy ${ }^{\circledR}$ Plant Mini Kit (33/50) resulting in the most detections of $X$. fastidiosa from leafhopper samples. As these two methods detected Xylella in the greatest number of infected samples, they may be more efficient to use for detection purposes in leafhoppers.
\end{abstract}

KEYWORDS: Citrus variegated chlorosis, vectors, nested-PCR.
RESUMO: A bactéria Xylella fastidiosa, agente causal da clorose variegada dos citros, é dependente da ação de insetos vetores para sua disseminação e infecção em plantas cítricas hospedeiras. Os insetos cigarrinhas (Hemiptera: Cicadellidae) transmitem a bactéria para plantas sadias depois de se alimentarem das plantas contaminadas. O objetivo deste trabalho foi desenvolver e comparar métodos de extração de DNA genômico de cigarrinhas a fim de detectar a bactéria $X$. fastidiosa. A extração de DNA foi realizada de acordo com protocolo à base de fenol-clorofórmio em conjunto com dois kits comerciais: Dneasy ${ }^{\circledR}$ Plant Mini Kit and Blood \& Tissue Dneasy ${ }^{\circledR}$ Handbook (Qiagen Inc., Valencia, CA, USA). Utilizou-se a cabeça das seguintes espécies de cigarrinhas: $D$. costalimai, A. citrina, O. facialis, B. xanthophis, M. leucomelas e $H$. ignorata. Com base nas diferenças numéricas entre as amostras independentes, os resultados mostraram o uso do método de extração fenol-clorofórmio (36/50 positivos) e o kit comercial DNeasy ${ }^{\circledR}$ Plant Mini Kit (33/50) resultando nas maiores detecções de $X$. fastidiosa nas amostras de cigarrinhas. Como esses dois métodos detectaram a presença de $X$. fastidiosa no maior número de amostras infectadas, eles podem ser mais eficientes para o uso na detecção em cigarrinhas.

PALAVRAS-CHAVE: clorose variegada dos citros; vetores; nested PCR. 
Citrus variegated chlorosis (CVC) affects citrus production in Brazil and was first described here in 1987 in the northern region of the state of Sáo Paulo (ROSSETTI et al., 1990). The causal agent is the bacteria Xylella fastidiosa (WELLS et al., 1987), transmitted to susceptible citrus species by leafhopper vectors (Hemiptera: Cicadellidae). The Xylella with ecdysis, as they transition from instar or are adults (LOPES, 1996).

HOPKINS (1983) demonstrated that the bacteria multiplies and attaches to the food canal (precibarium) and the suction chamber (cibarium) of the leafhopper Graphocephala atropunctata. LOPES (1996) verified that bacteria of $X$. fastidiosa were concentrated in plaques adhered to specific locations in the insect. The bacteria $X$. fastidiosa is detected in vector leafhoppers by the extraction of genomic DNA from the insects. There are different protocols for DNA extraction, however the most frequently used for vector insects is based on phenol-chloroform extraction. SAMBROOK et al. (1989) described the methodology with protocols based on phenol-chloroform for various DNA extraction procedures of many different sources. This methodology is also used for the extraction of proteins and nucleic acids, using ethanol for precipitation.

The Polymerase Chain Reaction (PCR) can be used to diagnose $X$. fastidiosa in infected plant tissue (HILL; PURCELL, 1995). This technique is based on the use of primers that allow the detection of as few as 10 to 100 bacteria per amplification reaction (POOLER; HARTUNG, 1995). The use of this technique to detect the bacteria in vector insects has been used by many authors (MARUCCI et al., 2003; CIAPINA et al., 2004). Nested-PCR is an efficient method for detecting organisms or products in samples with low concentration of DNA and/or high concentrations of contaminants that can inhibit or impede the amplification process. Particularly, the detection of $X$. fastidiosa can be challenging due to the low bacterial titer present in the vector insects (CIAPINA et al., 2004). Several other issues can be involved with DNA extraction from vector insects and the subsequent detection of $X$. fastidiosa. Studies that compare and establish efficient, reliable, specific and sensitive protocols are valuable to better understand the transmission mechanism and the capacity for the vector leafhoppers of $X$. fastidiosa to cause infection of the citrus host.

The objective of this work was to test and compare protocols for extraction of genomic DNA from leafhoppers combined with nested-PCR for the detection of the $X$. fastidiosa bacteria.

The leafhopper vectors were collected in commercial sweet orange orchards [Citrus sinensis (L.) Osbeck.], from the varieties Pera, Valencia and Folha Murcha. The orchards were in the cities of Nova Esperança and Mandaguaçu, in the northwestern region Paraná state, Brazil. The collection was undertaken from 2006 to 2009.

The leafhopper (Hemiptera: Cicadellidae) species sampled were A. citrina, D. costalimai, O. facialis, B. xanthofis and
M. cavifrons. The insects were captured in the orchards using yellow tape traps $\left(\right.$ Biocontrole $^{\circledast}$ ), distributed in the orchard on cards $(9 \times 12 \mathrm{~cm})$, and attached in tree tops facing north at a height of $1.70 \mathrm{~m}$. Each plant was considered a sampling unit. The traps were deployed with two replicate traps per sample row (on the $5^{\text {th }}$ and $50^{\text {th }}$ plants). There were five rows of each variety per plot, totalizing ten traps.

The samples were identified with the date, location and the plant from which they were collected. After collection, the leafhoppers were identified, and the heads were removed and transferred to $1.5 \mathrm{~mL}$ micro tubes. Samples were stored at $-4^{\circ} \mathrm{C}$ prior to DNA extraction at the Molecular Biology Laboratory, Nucleus of Research in Applied Biotechnology (NBA), State University of Maringá (UEM).

The identified and classified samples were used to compare three different DNA extraction methods. Two extraction Kits, the DNeasy ${ }^{\circledR}$ Blood \& Tissue Kit (Qiagen Inc., Valencia, CA, USA), the DNeasy ${ }^{\circledast}$ Plant Mini Kit (Qiagen Inc., Valencia, CA, USA) and a protocol based on phenol-chloroform extraction were compared.

One hundred and fifty leafhoppers were randomly selected from the sample comprising the four years of collection. The groups of 150 insects were subsequently divided in three groups of 50 for DNA extraction using these three methods. For DNA extraction the leafhopper's head was considered a sample ( 1 head per $1.5 \mathrm{~mL}$ micro tube). The samples were crushed with the addition of liquid nitrogen (MOLINA et al., 2013).

- Protocol I. After the initial crushing process $500 \mu \mathrm{L}$ of the extraction buffer was added $(50 \mathrm{mM}$ tri- $\mathrm{HCl} \mathrm{pH} 8.0$; $50 \mathrm{mM}$ EDTA; $10 \mathrm{mM}$ of $\mathrm{NaCl} ; 1.5 \mathrm{mM}$ of sarcosil; $1 \mathrm{mg} / \mathrm{mL}$ of proteinase-K). The lysis solution was incubated at $60^{\circ} \mathrm{C}$ for three hours and mixed every $30 \mathrm{~min}-$ utes. After incubation, $500 \mu \mathrm{L}$ of phenol: chloroform: isoamyl alcohol $(25: 24: 1 \mathrm{~mL})$ was added and the solution was centrifuged for 20 minutes at $4,000 \mathrm{rpm}$ and room temperature. The supernatant was transferred to a fresh micro tube and $500 \mathrm{uL}$ of phenol $(\mathrm{pH} \mathrm{8.0)}$ was added and the solution centrifuged for 20 minutes at 4,000 rpm. An equal volume of chloroform was added to the supernatant:isoamyl alcohol mix $(25: 24: 1 \mathrm{~mL})$ and the resulting solution was centrifuged for 20 minutes at $4,000 \mathrm{rpm}$. The DNA was precipitated with $20 \mu \mathrm{L}$ of $\mathrm{NaCl}$ (5M) $0.2 \mathrm{M}$ and $365 \mu \mathrm{L}$ or 0.7 volume of isopropanol. The micro tubes were covered and submerged in liquid nitrogen for 10 minutes and centrifuged at 14,000 rpm for 30 minutes at room temperature. The DNA was washed with $70 \%$ ethanol and centrifuged at 14,000 rpm for 10 minutes. The supernatant was discarded, and the pellet resuspended in $100 \mu \mathrm{L} \mathrm{TE}(1 \mathrm{mM}$ Tris- $\mathrm{HCl} \mathrm{pH}$ 8.0; $0.1 \mathrm{mM}$ EDTA) and maintained overnight. Purification of the DNA was performed by addition of $5 \mu \mathrm{L}$ RNase $(20 \mathrm{mg} / \mathrm{mL})$ with incubation for one hour at $37^{\circ} \mathrm{C}$. 
- Protocol II. The second method used in the total DNA extraction test from leafhopper heads was the DNeasy ${ }^{\oplus}$ Plant Mini Kit (Qiagen Inc., Valencia, CA, USA). The procedures adopted for the total DNA extraction followed manufacturer's instructions.

- Protocol III. The third protocol tested was a Kit specific for animal tissue, the DNeasy ${ }^{\circledR}$ Blood \& Tissue Kit (Qiagen Inc., Valencia, CA, USA). Manufacturer's instructions were followed for DNA extractions.

Gel electrophoresis was used to verify the quality of the extracted DNA and was performed in $0.8 \%$ agarose gel. A sample from each of the micro tubes ( $3 \mathrm{~mL}$ of Milli-Q water, $1 \mathrm{~mL}$ of bromophenol blue dye and $2 \mathrm{~mL}$ of the DNA solution) was added to the wells. Lambda marker $(\lambda)$, at concentrations of 25,50 and $100 \mathrm{ng} / \mathrm{mL}$, was used as the standard for size comparison. The gel was stained with $2 \mu \mathrm{L}$ of ethidium bromide, visualized and photographed under ultraviolet light on photo-documentation equipment (UVP GDS-8000 System).

The Nested-PCR was used for the detection of $X$. fastidios $a$ in DNA samples extracted from leafhoppers' heads. The primers used were those described by Pooler; Hartung (1995). Primers for were 272-1 (5'AGCGGGCCAATATTCAATTGC-3') and 272-2 (5'AGCGGGCCAAAACGATGCGTG3') that detect all subspecies of $X$. fastidiosa, and result in a $700 \mathrm{bp}$ amplicon when detected. For the second reaction in the nested PCR, the amplification of the first reaction was the model, and additional primers specific for $X$. fastidiosa were used: CVC-P1 (5'AGATGAAAACAATCATGCAAAA3') and 272-2-int (5'GCCGCTTCGGAGAGCATTCCT3'). Detection results in a $500 \mathrm{bp}$ amplicon.

The two PCR reactions were conducted with a total volume of $25 \mu \mathrm{L}$ comprising $2.5 \mu \mathrm{L}$ of $10 \mathrm{X}$ buffer $(200 \mathrm{mM}$ Tris-HCl; $\mathrm{pH}$ 8.4; $500 \mathrm{mM} \mathrm{Kcl}$ ); milli-Q water, $\mathrm{MgCl}_{2}$ (2.5 mM), DNTP (10 mM), $15 \mathrm{ng}$ of primer 272-1 and 272-2,
$40 \mathrm{ng}$ of total DNA sample; $1 \mathrm{U}$ of Taq-DNA-polimerase $\left(\right.$ Invitrogen $\left.{ }^{\circledast}\right)$. The amplification conditions were described by MOLINA et al. (2013) and MARUCCI (2003). The reaction was performed in a Master Cycler Gradient (Eppendorf). Subsequent to the first reaction, a second PCR was prepared using $5 \mu \mathrm{L}$ from the first reaction in place of the sample DNA and using primers CVC-1 and 272-2 int. Reaction conditions were as described above.

In all PCR tests, samples of known Xylella-infected plants were used as a positive control, with an additional positive control of infected leafhoppers (previously fed on $X$. fastidiosa infected plant-sources). Healthy leafhoppers free from bacteria and a sterile water blank were used as negative controls.

All three DNA extraction protocols compared in this study detected Xylella in all sharpshooter species screened. The samples of sharpshooters tested belong to the family Cicadellidae and include the species $A$. citrina, D. costalimai, O. facialis, B. xanthophis and M. cavifrons. However, protocols I (phenol: chloroform) and II (DNeasy ${ }^{\circledR}$ Plant Mini Kit) detected Xylella in more samples compared to protocol III (DNeasy ${ }^{\circledR}$ Blood \& Tissue Kit).

Prior to the nested PCR, the extracted DNA samples were all evaluated on a $1 \%$ agarose gel to verify integrity and to approximate quantity. The estimated DNA concentration was $40 \mathrm{ng} / \mathrm{mL}$. For the detection of $X$. fastidiosa in the vector insects, the results of nested-PCR confirmed presence of Xylella in positive samples with amplification of a $600 \mathrm{bp}$ fragment (Fig. 1).

The results indicated numeric differences between the independent samples in incidence of detection. Using the 50 potential leafhopper vectors, the phenol-chloroform based DNA extraction protocol (Protocol I) showed that 36 samples were positive $(72 \%)$. From these samples, 12 of the leafhoppers were $D$. costalimai, 10 were $A$. citrina, 7 were $O$. facialis, 4 were $B$. xanthophis and 3 were $M$. cavifrons. The DNeasy ${ }^{\circledR}$
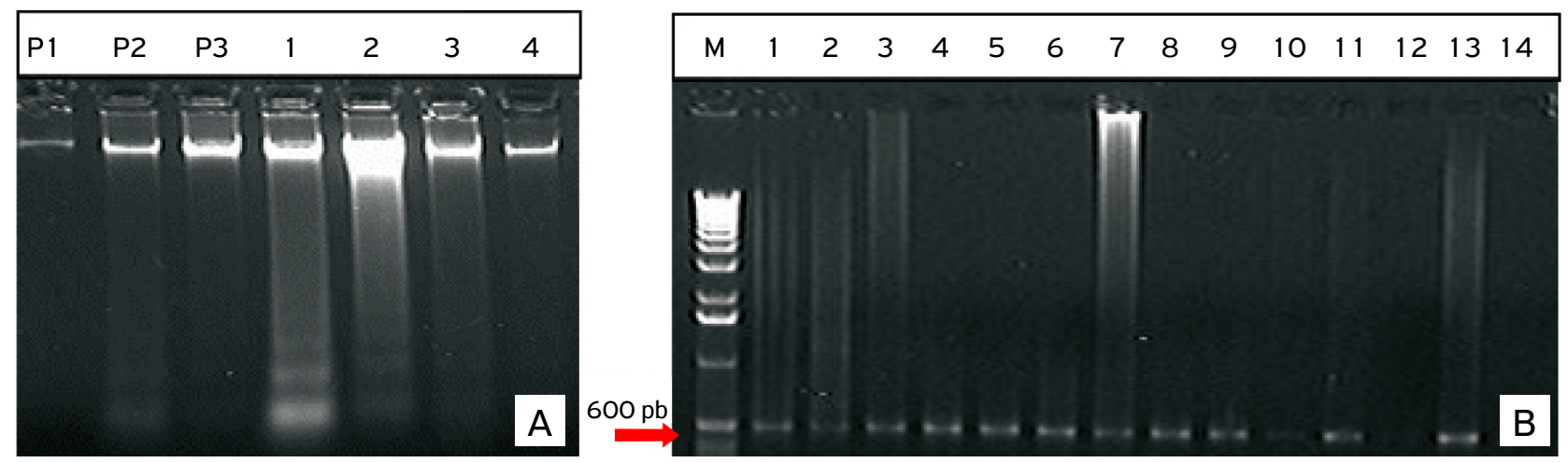

Figure 1. Where A: DNA quantification on $0.8 \%$ agarose gel; P1 Lambda marker, $25 \mathrm{ng} / \mathrm{mL} ; \mathrm{P} 2$. Lambda marker $50 \mathrm{ng} / \mathrm{mL} ; \mathrm{P} 3$. Lambda marker $100 \mathrm{ng} / \mathrm{mL}$; Samples 1 and 3 are the product of the extraction of total DNA from 3 heads and sample 4 from 1 head of sharpshooters (Dilobopterus costalimai); B: Nested-PCR using products, obtained from the DNA amplification reaction of the sharpshooter vectors of Xylella. $\mathrm{M}=$ molecular weight marker ( 1 -Kb DNA ladder (Invitrogen ${ }^{\circledR}$ ); Samples 1 to $12=$ sharpshooter (Dilobopterus costalimai). Sample 13 is a positive control from a sharpshooter, and sample 14 is a negative control. An amplicon at $600 \mathrm{bp}$ indicates a positive detection of Xylella in that sample. 
Plant Mini Kit (Protocolo II) detected Xylella in 33 leafhopper samples, of which 11 were $D$. costalimai, 10 were $A$. citrina, 7 were $O$. facialis, 2 were B. xanthophis and 3 were $M$. cavifrons. In the 50 leafhopper samples tested after DNA extraction using the DNeasy ${ }^{\circledR}$ Blood \& Tissue Kit (Protocolo III), 19 tested positive for Xylella. These included 2 samples of D. costalimai, 7 of $A$. citrina, 5 of $O$. facialis, 2 of B. xanthophis and 3 of $M$. cavifrons (Table 1).

CIAPINA et al. (2004) suggest that the detection of X. fastidios $a$ in insect samples can be challenging due to the low titer of bacterial cells present in insects. In many cases, DNA extraction is not efficient and several other molecules can be extracted alongside the DNA, which can inhibit the PCR reaction, generating a false-negative result. MCELRONE et al. (1999) studied 27 plant species which were identified as possible alternative hosts of X. fastidiosa. Six plant species were positive for Xylella, and 11 species had ambiguous results based on the amplification reaction, probably due to the interference in the PCR by various plant compounds that inhibited the process. CIAPINA et al. (2004) and MARUCCI (2003) used DNA extraction methods, with subsequent amplification using nested-PCR to compare DNA extraction's efficiency and quality by subsequent detection of $X$. fastidiosa in plant samples and vector insects.
To find a fast, easy and efficient process to detect $X$. fastidiosa, HUANG et al. (2006) tested the DNeasy ${ }^{\circledast}$ Plant Mini Kit in 30 samples of leafhopper vectors. In that study, the authors detected 15 positive samples using the nested-PCR technique. These observations and results from other studies are confirmed in the present article. Based on the number of positive samples, we found the DNA extraction using the DNeasy ${ }^{\circledR}$ Plant Mini Kit the second best method for the diagnosis of $X$. fastidiosa when combined with nested-PCR.

Based on the obtained results, the most effective DNA extraction methods for $X$. fastidiosa from leafhopper vectors were the phenol-chloroform extraction and the commercial DNeasy ${ }^{\circledast}$ Plant Mini Kit. Both methods detected Xylella in most of the samples.

\section{ACKNOWLEDGEMENTS}

We acknowledge support 'Coordenadoria de Aperfeiçoamento de Pessoal de Nível Superior' (CAPES) and Conselho Nacional de Desenvolvimento Científico e Tecnológico (CNPq).

Table 1. Comparison among DNA extraction methods for the detection of $X$. fastidiosa bacteria in sweet orange using nested-PCR.

\begin{tabular}{|c|c|c|c|c|c|c|}
\hline \multirow[b]{2}{*}{ Species } & \multicolumn{2}{|c|}{ Protocol I * } & \multicolumn{2}{|c|}{ Protocol II** } & \multicolumn{2}{|c|}{ Protocol III*** } \\
\hline & $\begin{array}{c}\text { Total } \\
\text { samples }\end{array}$ & Samples (+) & $\begin{array}{c}\text { Total } \\
\text { samples }\end{array}$ & Samples (+) & $\begin{array}{c}\text { Total } \\
\text { samples }\end{array}$ & Samples (+) \\
\hline Dilobopterus costalimai & 15 & 12 & 15 & 11 & 15 & 2 \\
\hline Acrogonia citrina & 15 & 10 & 15 & 10 & 15 & 7 \\
\hline Oncometopia facialis & 10 & 7 & 10 & 7 & 10 & 5 \\
\hline Bucephalogonia xanthofis & 5 & 4 & 5 & 2 & 5 & 2 \\
\hline Macugonalia cavifrons & 5 & 3 & 5 & 3 & 5 & 3 \\
\hline Total & 50 & 36 & 50 & 33 & 50 & 19 \\
\hline
\end{tabular}

*Phenol -chloroform; ** Kit DNeasy ${ }^{\circledast}$ Plant Mini Kit (Qiagen Inc., Valencia, CA, USA); *** DNeasy ${ }^{\circledR}$ blood \& tissue Handbook (Qiagen Inc., Valencia, CA, USA).

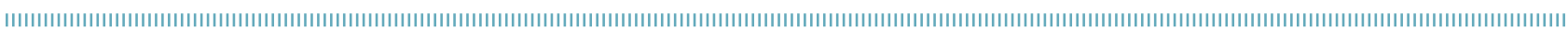
REFERENCES

CIAPINA, L.P.; CARARETO ALVES, L.M.; LEMOS, E.G.M. A nested-PCR assay for detection of Xylella fastidiosa in citrus plants and sharpshooter leafhoppers. Journal of Applied Microbiology, v.96, n.3, p.546-551, 2004.

HILL, B.L.; PURCELL, A.H. Multiplication and movement of Xylella fastidiosa within grape and four other plants. Phytopathology, v.85, n 1 1, p.1368-1372, 1995. http://dx.doi.org/10.1094/ Phyto-85-1368

HOPKINS, D.L. Gram-negative, xylem-limited bacteria in plant disease. Phytopathology, v.73, n.2, p.347-350, 1983.
HUANG, Q.; BENTZ, J.; SHERALD, J.L. Fast and efficient DNA extraction and one-step polymerase chain reaction for the detection of $X y / e l l a$ fastidiosa in potential insect vectors. Journal of Plant Pathology, v.88, n. 1, p.77-81, 2006. http://dx.doi.org/10.4454/jpp.v88i 1.833

LOPES, J.R.S. Mecanismo de transmissão de Xylella fastidiosa por Cigarrinhas. Laranja, v.17, n. 1, p.79-92, 1996.

MARUCCI,R.C;GIUSTOLIN, T.A.;MIRANDA, M.P.;MIQUELOTE,H.; ALMEIDA, R.P.P.; LOPES, J.R.S. Identification of a non-host plant of Xylella fastidiosa to rear healthy sharpshooter vectors. ScientiaAgricola, v.60, n.4, p.669-675, 2003. http://dx.doi.org/10.1590/SO103-90162003000400010 
McELRONE, A.J.; SHERALD, L.J.; POOLER, M.R. Identification of alternative hosts of $X$. fastidiosa in the Washington, D. C., area using nested polymerase chain reaction (PCR). Journal of Arboriculture, v.25, n.5, p.258-262, 1999.

MOLINA, R.O.; GONÇALVES-ZULIANI, A.M.O.; ZANUTTO, C.A.; SOARES, L.S.; NUNES, W.M.C. Detecção de Xylella fastidiosa em cigarrinhas vetoras por meio da reação em cadeia da polimerase. Tecnologia \& Ciencia Agropecuária, v.7, n.4, p.13-17, 2013.

POOLER, M.R.; HARTUNG, J.S. Specific PCR detection and identification of Xylella fastidiosa strains causing citrus variegated chlorosis. Current Microbiology, v.31, n.6, p.134-137, 1995.
ROSSETTI, V.; GARNIER, M.B.; BERETTA, M.J.G.; TEIXEIRA, A.R.R.; QUAGGIO, J.A.; BATTAGLIA, O.C.; GOMES, M.P.; DE NEGRI, J.D.; BOVÉ, J.M. Resultados preliminares de estudos sobre uma nova anormalidade dos citros observada nos Estados de São Paulo e Minas Gerais. Summa Phytopathologica, v.16, n.2, p.1-13, 1990.

SAMBROOK, J.; MANIATIS, T.; FRITSCH, E.F. Molecular Cloning: a Laboratory Manual. New York: Cold Spring Harbor Laboratory, Cold Spring Harbor, 1989. 626p.

WELLS, J.M.; RAJU, B.C.; HUNG, H.Y.; WEISBURG, W.G.; MANDELCO-PAUL, L.; BRENNER, D.J. Xylella fastidiosa gen nov., sp. Nov. gramnegative, xylem limited fastidious plant bactéria related to Xanthomonas spp. International Journal of Systematic Bacteriology, v.37, n.2, p.136-143, 1987. 